\title{
Accreditation Status and Other Factors Affecting Patient Satisfaction in Hospital
}

\author{
Siwi Anggraini Sulistyo'), Didik Tamtomo²), Endang Sutisna Sulaeman²) \\ 1) Masters Program in Public Health, Univeritas Sebelas Maret \\ 2) Faculty of Medicine, Univesitas Sebelas Maret
}

\begin{abstract}
Background: Hospital accreditation is a systemic assessment to measure service quality according to standards. Hospital services focus on meeting patient needs and satisfaction. This study aimed to determine the status of accreditation and other factors that influence the satisfaction of hospitalized patients in the hospital.

Subjects andMethod: This was a cross sectional study conducted in four hospitals in Sleman, Yogyakarta, from March to April 2019. A sample 200 inpatients were selected for this study by proportional random sampling. The dependent variable was patient satisfaction. The independent variables were accreditation status, service quality, length of care, source of funds, employment, age, and gender. The data were collected by questionnaire and analyzed by path analysis.

Results: Patient satisfaction was directly and positively affected by age $>18$ years old $(b=2.34$; $95 \% \mathrm{CI}=0.33$ to $2.50 ; \mathrm{p}=0.023)$, gender $(\mathrm{b}=1.02 ; 95 \% \mathrm{CI}=0.08$ to $1.96 ; \mathrm{p}=0.034)$, length of care $>3$ days $(b=0.99 ; 95 \% \mathrm{CI}=0.043$ to $1.95 ; \mathrm{p}=0.041)$, independent funding sources $(\mathrm{b}=1.50$; $95 \% \mathrm{CI}=0.47$ to $2.53 ; \mathrm{p}=0.004)$, good service quality $(\mathrm{b}=3.42 ; 95 \% \mathrm{CI}=2.31$ to $4.53 ; \mathrm{p}<0.001)$, and good accreditation status $(\mathrm{b}=3.33 ; 95 \% \mathrm{CI}=2.12$ to $4.54 ; \mathrm{p}<0.001)$. Satisfaction is directly and negatively influenced by work $(\mathrm{b}=-1.37 ; 95 \% \mathrm{CI}=-2.32$ to $-0.41 ; \mathrm{p}=0.005)$. Patient satisfaction was influenced indirectly and positively by accreditation status through good service quality $(\mathrm{b}=0.70 ; 95 \% \mathrm{CI}=-0.04$ to $1.96 ; \mathrm{p}=0.037)$. Patient satisfaction was influenced indirectly by age $>18$ years through service quality $(b=1.50 ; 95 \% \mathrm{CI}=0.49$ to $2.50 ; \mathrm{p}=0.036)$.

Conclusions: Patient satisfaction was influenced directly and positively by age $>18$ years, male sex, length of care $>3$ days, independent fund sources, good service quality and good accreditation status. Patient satisfaction is influenced directly and negatively by work. Patient satisfaction was indirectly affected by age $>18$ years and good accreditation status.
\end{abstract}

Keywords: Patient satisfaction, accreditation status, path analysis

\section{Correspondence:}

Siwi Anggraini Sulistyo, Masters Program in Public Health, Universitas Sebelas Maret. Jl. Ir. Sutami 36 A, Surakarta 57126, Jawa Tengah. Email: siwianggraini@ymail.com. Mobile: 082330049892

\section{BACKGROUND}

Reform in the health sector is manifested in patient safety and patient-centered services (Brubakk et al., 2015). Health services are every effort organized in the form of an organization to improve public health through preventive, curative, and rehabilitative activities (Azwar, 2010). Based on Law Number 44 of 2009 concerning Hospitals, it is explained that the new paradigm of health services in Indonesia requires hospitals to provide quality services that refer to the professional code of ethics and according to patient needs (Government of Indonesia, 2009).

Health services need to pay attention to quality and service quality that will determine patient satisfaction and loyalty. Patient satisfaction can be improved through facility hygiene, privacy arrangements, and interpersonal service providers (Adhikary et al., 2018). Hospitals need to pay attention 
Journal of Health Policy and Management (2019), 4(3): 139-149

https://doi.org/10.26911/thejhpm.2019.04.03.01

to the completeness of facilities and fulfillment of health human resources including medical personnel and non-medical personnel to service patients. Patient satisfaction can be determined from the quality of the treatment process, and the quality of patient interactions with hospital staff (Zarei et al., 2014).

Patient's complaints about hospital services in the form of dissatisfaction can cause patients to be disappointed and not continue treatment at the hospital. Patient satisfaction is influenced by many factors, namely the level of employees, infrastructure, and characteristics of patients, namely age, gender, and occupation (Holtmannet al., 2011).

Aliman and Mohammad's (2016) study concluded that more than $70 \%$ of patient satisfaction comes from service quality consisting of reliability, responsiveness, conviction, and empathy for medical staff.

The number of hospitals in Indonesia currently is 2,820 agencies and hospitals that have been accredited amounting to 1,032 (36\%) hospitals (KARS, 2018). The number of hospitals in Yogyakarta in 2018 is 78 hospitals consisting of 55 general hospitals and 23 special hospitals. The number of hospitals in Yogyakarta that have been accredited is $53(68 \%)$ hospitals and 25 (32\%) have not been accredited. There are 28 hospitals in Sleman Regency and 22 accreditation hospitals (Yogyakarta Provincial Health Office, 2017).

Accreditation is an external assessment strategy to measure the quality of a health service. Hospital accreditation is needed as a systematic assessment of the overall organization of the organization including the performance of employees in performing services (Brubakk et al., 2015).

Hospitals will be encouraged to carry out quality services by applying accreditation standards. In addition, the hospital will strive to continue to increase cooperation and discipline among employees in performing services (Oliveira et al., 2017). Camillo et al. (2016) reported that hospital staff supported an accreditation system that would benefit hospitals in terms of improving the quality of management and public health services. This is supported by the development of professional skills of hospital staff and improving the financing management system, organizational structure, complete medical facilities and infrastructure, assistance management, and perceptions of pride/ job satisfaction.

The Minister of Health Regulation No. 71 of 2013 concerning Health Services at the National Health Insurance states that firstrate health facilities must be accredited and hospitals must have accreditation certificates. Hospital accreditation held in Indonesia can encourage efforts to improve hospital service quality and patient safety. Accreditation is an external assessment strategy carried out by the Government's official institution namely the Hospital Accreditation Committee (KARS) to measure the quality of a health service (Ministry of HealthRI, 2013). Preparations for facing accreditation assessments have seen a significant increase in service, which is $74 \%$. Accreditation has a greater negative impact (48\%) than positive effects (4\%) on post-accreditation employee performance (Devkaran and O'Farrell, 2015).

Sacket et al. (2010) reported that accreditation status was not related to patient satisfaction but it could be a reference for improving the quality of hospital management. This will improve the quality of hospital services so that patient satisfaction will be fulfilled and hospital profits will rise. The study of Kennedy et al. (2014) found that the size of the hospital building, the completeness of facilities and infrastructure, the volume of medical operations performed, 
and the low mortality rate of the hospital were much related and affected the satisfaction of patients who took medication.

This study aimed to determine the status of accreditation and other factors that influence hospital patient satisfaction.

\section{SUBJECTS AND METHOD \\ 1. Study Design}

This was an analytic observational study with a cross sectional design. The study was conducted in four hospitals in Sleman, Yogyakarta, Indoneisa, from March to April 2019.

\section{Population and Samples}

The target population of this study was all inpatients who were in 4 hospitals with different accreditation status in Sleman Regency, Yogyakarta. The hospitals were AtTurots Al Islamy Hospital, Queen Latifa Hospital, Sadewa Hospital, and Muhammadiyah Gamping Hospital. Total 200 inpatients were selected by proportional random sampling.

\section{Study Variables}

The dependent variable was patient satisfaction. The independent variables were accreditation status, service quality, length of care, source of funds, employment, age, and gender of the patient.

\section{Operational Definition of Variables} Accreditation status was the status issued by the Hospital Accreditation Committee (KARS) after the hospital goes through accreditation assessment in the form of an official certificate signed by the KARS leadership. Data collection was done using hospital secondary data.

The quality of service was the assessment of patients on the actions given by the hospital both medical and non-medical in meeting the needs of patients supported by available facilities and infrastructure.

Duration of treatment was the time needed by patients while undergoing treat- ment at the hospital from the first stay in the hospital as an inpatient.

The source of funds was the origin of the costs that will be used to pay for all the patient's needs while in the hospital.

Occupationwas an activity carried out by respondents to earn income in order to meet their daily needs. The data collection was done using questionnaires. The measurement scale was dichotomy.

Age was the age of the patient at the time of hospitalization which was calculated from the year of birth until the study takes place.

Gender was a biological condition that exists from birth and becomes the patient's identity to distinguish women and men.

\section{Study Instruments}

Data obtained from hospital documents in the form of official certificates issued by the Hospital Accreditation Committee (KARS) after the hospital conducts accreditation assessments. Duration of treatment comes from medical records of inpatients. Satisfaction, service quality, source of funds, employment, age, and sex of respondents were collected by questionnaire.

\section{Data Analysis}

The data analyzed by univariate analysis with sample characteristics, bivariate analysis with Chi-Square, and multivariate analysis with path analysis with STATA program 14. The data management was done using Path analysis through path specifications, model identification, structural models, parameter estimation, and model respecification.

\section{Research Ethics}

Research ethics include approval sheets, anonymity, confidentiality, and ethical feasibility. The ethical feasibility in this study came from the Health Research Ethics Committee of the Regional General Hospital Dr. Moewardi Surakarta with number: 319 / III / HREC / 2019. 


\section{RESULTS \\ 1. Samples Characteristics}

Table 1 show that there are 177 patients (88.5\%) who are $>18$ years old. 103 patients (51.5\%) were female and 104 patients (52\%) did not work. The number of patients treated $>3$ days was 102 patients (51\%). Patients

Table 1. Sample Characteristics

\begin{tabular}{lcc}
\hline Characteristics & $\mathbf{N}$ & $\mathbf{\%}$ \\
\hline Age & & \\
$<18$ years & 23 & 11.5 \\
$\geq 18$ years & 177 & 88.5 \\
Gender & & 51.5 \\
Female & 103 & 48.5 \\
Male & 97 & 52 \\
Occupation & & 48 \\
Not working & 104 & \\
Working & 96 & 49 \\
Treatment duration & & 51 \\
$<3$ days & 98 & 70 \\
>3 days & 102 & 30 \\
Insurce of care funce & & \\
Personal cost & 140 & 36 \\
Service quality & 60 & 64 \\
Poor & & \\
Good & 72 & 28.5 \\
Accreditation Status & 128 & 71.5 \\
Poor & & \\
Good & 57 & 42 \\
Notisfaction & 143 & 58 \\
Satisfied & & \\
\hline
\end{tabular}

\section{Bivariate Analysis}

Table 2 showed the results of bivariate analysis of independent variables and dependent variables. Table 2 showed that age $>18$ years old $(\mathrm{OR}=19 ; \mathrm{p}<0.001)$, male gender $(\mathrm{OR}=2.68 ; \mathrm{p}=0.001)$, duration of treatment $>3$ days $(\mathrm{OR}=2.08 ; \mathrm{p}=0.011)$, inde- who were hospitalized used insurance as much as 140 (70\%). Patients who assessed the quality of hospital services as good as 128 (64\%) and satisfied patients as many as 116 patients (58\%). Hospitals that had good accreditation were 143 (71.5\%).

pendent funds source $(\mathrm{OR}=2.60 ; \mathrm{p}=$ o.004), good service quality $(\mathrm{OR}=9.80 ; \mathrm{p}$ $<0.001)$, and good accreditation status $(\mathrm{OR}=13.46 ; \mathrm{p}<0.001)$ increased patient satisfaction with hospital services. Patients who have jobs $(\mathrm{OR}=0.38 ; \mathrm{p}=0.001)$ reduce satisfaction to hospital services. 
Sulistyo./ Accreditation Status and Other Factors Affecting Patient Satisfaction in Hospital

Table 2. The results of bivariate analysis of factors that influence patient satisfaction

\begin{tabular}{|c|c|c|c|c|c|c|c|c|}
\hline \multirow{3}{*}{ Variable } & \multicolumn{4}{|c|}{ Patients Satisfaction } & \multirow{2}{*}{\multicolumn{2}{|c|}{ Total }} & \multirow{3}{*}{ OR } & \multirow{3}{*}{$\mathbf{p}$} \\
\hline & \multicolumn{2}{|c|}{ Unsatisfied } & \multicolumn{2}{|c|}{ Satisfied } & & & & \\
\hline & $\mathbf{n}$ & \% & $\mathbf{n}$ & \% & $\mathbf{N}$ & \% & & \\
\hline \multicolumn{9}{|l|}{ Age } \\
\hline$<18$ years & 21 & 91.3 & 2 & 8.7 & 23 & 100.0 & \multirow{3}{*}{19} & \multirow{3}{*}{$<0.001$} \\
\hline$\geq 18$ years & 63 & 35.6 & 114 & 64.4 & 177 & 100.0 & & \\
\hline Gender & & & & & & & & \\
\hline Female & 55 & 53.4 & 48 & 46.6 & 103 & 100.0 & \multirow{3}{*}{2.68} & \multirow[b]{2}{*}{0.001} \\
\hline Male & 29 & 29.9 & 68 & 70.1 & 97 & 100.0 & & \\
\hline \multicolumn{8}{|l|}{ Occupation } & \\
\hline Not working & 32 & 30.8 & 72 & 69.2 & 104 & 100.0 & \multirow{3}{*}{0.38} & \multirow{3}{*}{0.001} \\
\hline Working & 52 & 54.2 & 44 & 45.8 & 96 & 100.0 & & \\
\hline \multicolumn{7}{|c|}{ Treatment duration } & & \\
\hline$<3$ days & 50 & 51.0 & 48 & 49.0 & 98 & 100.0 & \multirow{3}{*}{2.08} & \multirow{3}{*}{0.011} \\
\hline$\geq 3$ days & 34 & 33.3 & 68 & 66.7 & 102 & 100.0 & & \\
\hline \multicolumn{7}{|c|}{ Source of care funds } & & \\
\hline Insurance & 68 & 48.6 & 72 & 51.4 & 140 & 100.0 & \multirow{3}{*}{2.60} & \multirow{3}{*}{0.004} \\
\hline Personal & 16 & 26.7 & 44 & 73.3 & 60 & 100.0 & & \\
\hline \multicolumn{7}{|l|}{ Service quality } & & \\
\hline Poor & 54 & 75.0 & 18 & 25.0 & 72 & 100.0 & \multirow{3}{*}{9.80} & \multirow{3}{*}{$<0.001$} \\
\hline Good & 30 & 23.4 & 98 & 76.6 & 128 & 100.0 & & \\
\hline \multicolumn{7}{|c|}{ Accreditation Status } & & \\
\hline Poor & 47 & 82.5 & 10 & 17.5 & 57 & 100.0 & \multirow{2}{*}{13.46} & \multirow{2}{*}{$<0.001$} \\
\hline Good & 37 & 25.9 & 106 & 74.1 & 143 & 100.0 & & \\
\hline
\end{tabular}

\section{Path Analysis}

Table 3 showed the results of path analysis. Patient satisfaction was directly and positively affected by age $>18$ years old and it was statistically significant. Inpatients aged $>18$ years old have logodd to be satisfied with hospital services by 2.34 units higher than inpatients who were $<18$ years old $(b=2.34 ; 95 \% C I=0.33$ to $4.35 ; p=0.023$ ).

Patient satisfaction was influenced directly and positively by male gender and proved to be statistically significant. Male inpatients had logodd to be satisfied with hospital services by 1.02 units higher than female inpatients $(b=1.02 ; 95 \% \mathrm{CI}=0.08$ to 1.96; $\mathrm{p}=0.034$ ).

Patient satisfaction was influenced directly and negatively by employment and it was statistically significant. Patients who work have logodd to be satisfied with hospital services by -1.37 units lower than inpatients who did not work $(b=-1.37 ; 95 \% C I=-$

\subsection{3 to $-0.41 ; \mathrm{p}=0.005)$.}

Patient satisfaction was influenced directly and positively by length of treatment $>3$ days and it was statistically significant. Patients who were hospitalized for $>3$ days had logodd to be satisfied with hospital services by 0.99 units higher than patients who were hospitalized for $<3$ days in hospital $(b=0.99$; CI 95\% $=0.04$ to 1.95; $\mathrm{p}=0.041)$.

Patient satisfaction was influenced directly and positively by independent funding sources and it was proven to be statistically significant. Patients who use independent funding sources have logodd to be satisfied with hospital services by 1.50 units higher than inpatients with health insurance $(b=1.50 ; 95 \% \mathrm{CI}=0.47$ to $2.53 ; \mathrm{p}=$ 0.004).

Patient satisfaction was influenced directly and positively by good service quality and it was statistically significant. Hospitals 
Journal of Health Policy and Management (2019), 4(3): 139-149

https://doi.org/10.26911/thejhpm.2019.04.03.01

that have good service quality have logodd by 3.42 units higher for inpatient satisfaction than hospitals with poor service quality $(b=3.42 ; 95 \% \mathrm{CI}=2.31$ to $4.53 ; \mathrm{p}<$ o.001).

Patient satisfaction was influenced directly and positively by the status of the hospital accreditation and it was statistically significant. The good status of hospital accreditation has logodd for increasing patient satisfaction by 3.33 units higher than hospitals that have poor accreditation status $(b=3.33 ; 95 \% \mathrm{CI}=2.12$ to 4.54 ; $\mathrm{p}<0.001)$.

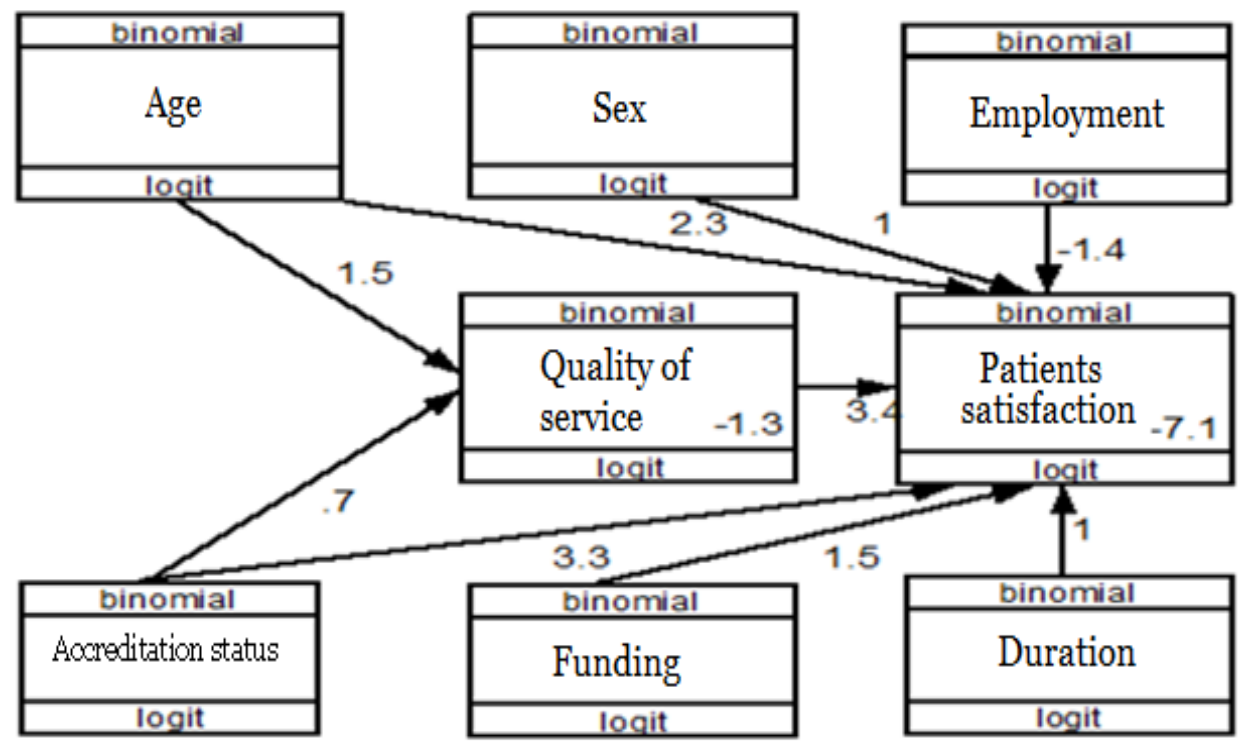

Figure 1. Path analysis model with estimation

Patient satisfaction was influenced indirectly and positively by accreditation status through service quality. Good accreditation status has logod for good service quality by 0.70 units higher than poor accreditation status $(b=0.70 ; 95 \% \mathrm{CI}=-0.04$ to $1.96 ; \mathrm{p}=$ o.037).

Table 3. The results of path analysis of factors that influence patient satisfaction in the hospital

\begin{tabular}{|c|c|c|c|c|c|c|}
\hline \multirow{2}{*}{$\begin{array}{c}\text { Dependent } \\
\text { Variable }\end{array}$} & & \multirow[b]{2}{*}{ Independent Variable } & \multirow[b]{2}{*}{$\mathbf{b}$} & \multicolumn{2}{|c|}{$95 \% \mathrm{CI}$} & \multirow[b]{2}{*}{$\mathbf{p}$} \\
\hline & & & & $\begin{array}{c}\text { Lower } \\
\text { limit }\end{array}$ & $\begin{array}{c}\text { Upper } \\
\text { limit }\end{array}$ & \\
\hline \multicolumn{7}{|l|}{ Direct Effect } \\
\hline Patients satisfaction & $\leftarrow$ & Age $>18$ years old & 2.34 & 0.33 & 4.35 & 0.023 \\
\hline Patients satisfaction & & Male & 1.02 & 0.08 & 1.96 & 0.034 \\
\hline Patients satisfaction & & Employed & -1.37 & -2.33 & -0.41 & 0.005 \\
\hline Patients satisfaction & & Length of treatment $>3$ days & 0.99 & 0.04 & 1.95 & 0.041 \\
\hline Patients satisfaction & & Personal funds source & 1.50 & 0.47 & 2.53 & 0.004 \\
\hline Patients satisfaction & & Good service quality & 3.42 & 2.31 & 4.53 & $<0.001$ \\
\hline $\begin{array}{l}\text { Patients satisfaction } \\
\text { Indirect Effect }\end{array}$ & & Accreditation status & $3 \cdot 33$ & 2.12 & 4.54 & $<0.001$ \\
\hline Service quality & $\leftarrow$ & Accreditation status & 0.70 & 0.04 & 1.96 & 0.037 \\
\hline $\begin{array}{l}\text { Service quality } \\
\text { N obsevation }=200 \\
\text { Log likelihood }=-183\end{array}$ & & Age $\geq 18$ years old & 1.50 & 0.49 & 2.50 & 0.004 \\
\hline
\end{tabular}
quality of hospital services. Ages $>18$ years old have logods to assess the service quality by 1.50 units higher than patients aged $<18$ years old $(b=1.50 ; 95 \% \mathrm{CI}=0.49$ to $2.50 ; \mathrm{p}=$ $0.036)$

Patient satisfaction was influenced indirectly by age $>18$ years old through the 


\section{DISCUSSIONS \\ 1. The effect of age on patients satis- faction}

The results of the analysis showed that age has a direct and positive influence on patient satisfaction and it was statistically significant. The older the patient, the higher his satisfaction. Age also has a direct and positive effect on service quality assessment. The older the patients, the better the quality of the service.

Study of Kurniawan et al. (2019) reported that the age of $>35$ years old increased the level of satisfaction by 0.99 times compared to patients <35 years old. The enhancement of age can have an effect on health, which was deterioration in the structure and function of organs, so that older people tend to use health services more than young people.

Some older people who experienced chronic illnesses were more receptive to their physical limitations than younger people. This was because older people were generally more open, so older patients demand lower expectations from young patients. This caused older patients to be more satisfied than younger patients(Haj-Ali et al., 2014).

\section{The effect of gender on patients satisfaction}

The results of the analysis showed that gender had a direct and positive influence on patient satisfaction and it was statistically significant. Male patients had greater satisfaction than female patients.

A study by Oroh et al. (2014) showed that there was a relationship between genders with the level of patient satisfaction. Gender has an influence on patient satisfaction because the view of the services provided by hospitals between women and men was different.

Women see more appearance in detail, while men have views that tend to be more indifferent to things around them so men were considered more flexible than women (Tjiptono, 2014).

\section{The Effect of Employment on Pa- tients Satisfaction}

The results of the analysis showed that employment had a direct and negative influence on patient satisfaction and it was statistically significant. Patients who worked had lower satisfaction than patients who did not work.

This study was supported by Hidayati et al., (2014) who reported that there was a relationship between work and patient satisfaction. Job was a predisposing character and demographic characteristics of individuals that can affect the patient's perception in the process of healing the disease.

Individuals who worked have a habit to always focus on their work and service opinions according to their needs, so that perceptions of health services were differrent from individuals who did not work. Working individuals tend to be very dependent on health services while non-working individuals tend to be independent (Lupiyoadi, 2013).

\section{The Effect of Funds Source on Patients Satisfaction}

The results of the analysis showed that the source of funds had a direct and positive influence on patient satisfaction and it was statistically significant. Patients who use independent costs have higher satisfaction than patients with insurance.

The results of this study were supported by Sari (2015) who examined the differences in the level of satisfaction of BPJS patients with general patients at Dr. RSUD Soediran Mangun Sunarso in Wonogiri who concluded that the level of satisfaction of general patients was $39.51 \%$ higher than BPJS Health patients. Tjiptono (2014) stated thatthere were several things that 
make customers in the health sector or patients satisfied namely equipment or facilities, staff competency and the accuracy of handling patient complaints.

A study by Agheorghiesei and Copoeru (2013) showed that needs that were directly related to a person's condition such as the use of facilities, the quality of services and the relationship between patients and health personnels affected the patient's assessment of the quality of health services.

\section{The Effect of Length of Treatment on Patients Satisfaction}

The results of the analysis showed that the length of treatment has a direct and positive influence on patient satisfaction and it was statistically significant. The longer the treatment, the better the patient satisfaction.

The results of this study was supported by Oroh et al. (2014) who stated that the treatment duration of 2 to 6 days was related to the level of patient satisfaction. The duration of hospitalization in a hospital can be seen from two approaches, the first came from the type of disease suffered by the patient takes a long time and the second was the patient felt comfortable and satisfied in doing the treatment.

Patients who were hospitalized for longer had more interactions and frequency with health personnels than patients who were only briefly admitted to the hospital. This increased the attention and empathy of health staff to patients. The form of empathy from hospital staff was a special concern for patient and family complaints (Sumarwan, 2011).

Patient satisfaction can be influenced by the quality of health services, especially in the empathy dimension that would increase patient satisfaction by 0.496 times. Empathy from staff in caring for patients was needed to form closeness between patients and officers (Alghamdi, 2014).

\section{The Effect of Service Quality on Patients Satisfaction $n$}

The results of the analysis showed that service quality has a direct and positive influence on patient satisfaction and it was statistically significant. The better the quality of service, the better patient satisfaction.

This study was supported byWidayati et al., (2018)who stated thatpatient satisfaction can be influenced by income, education, and quality of service. Another study by Fuad (2017) also reported that the speed of service increased the patient satisfaction by 1.91 units. The availability of medical facilities and the environment in the hospital has a direct effect on patient satisfaction, but the effectiveness of treatment given by the hospital has more influence on patient satisfaction (Kim et al., 2017). Study by Péfoyo and Wodchis (2013) stated that hospital performance indicators were directly related to patient satisfaction. The study also mentioned that there was a need to match the patient's social status and hospital level in evaluating patient satisfaction.

\section{The Effect of Accreditation Status on Patients Satisfaction}

The results of the analysis showed that the accrediation status has a direct and positive influence on patient satisfaction and it was statistically significant. The better the accreditation status, the better the patient satisfaction.

The results of the study were supported by Holtmann et al. (2011) who stated that good accreditation status both affected the satisfaction of inpatients by 0.98 times.

The results of the analysis also showed that the accreditation status has a direct and positive effect on service quality and it was statistically significant. The better the status of hospital accreditation, the better the quality of services provided.

Accreditation status was needed to guarantee the quality of patient health and 
safety services. Hospital accreditation was an external assessment strategy for measuring the quality of a health service (Brubakk et al., 2015). Hospitals would be encouraged to carry out quality services by applying existing accreditation standards. In addition, the hospital would strive to continue to increase cooperation and discipline among employees in performing services (Oliveira et al., 2017)

Measurement of patient satisfaction at the hospital was needed in developing and implementing a hospital accreditation system. Accreditation was one of the determinants of patient satisfaction driven by the completeness of other facilities and infrastructure(Haj-Ali et al., 2014).

\section{AUTHORS CONTRIBUTION}

Siwi Anggraini Sulistyo, the main author, played a role in collecting and processing study data. Didik Tamtomo examined the conceptual framework and study methodology. Endang Sutisna Sulaeman reviewed the study manuscript.

FUNDING AND SPONSORSHIP

This study used personal costs by the main author.

\section{ACKNOWLEDGEMENT}

$\overline{\text { The authors would like to thank personnel }}$ at the four hospitals in Sleman, Yogyakarta, for for facilitating data collection.

\section{CONFLICT OF INTEREST}

The author did not have any conflict of interest.

\section{REFERENCES}

$\overline{\text { Agheorghiesei DT, Copoeru I (2013). Eva- }}$ luating patient satisfaction - a matter of ethics in the context of the accreditation process of the romanian hospitals. Procedia - social and behavioral sciences, 82(2013): 404-410.https://dx.doi.org/10.1016/j.sbspro.2013.06. 283

Adhikary G, Shawon MSR, Ali MW, Shamsuzzaman M, Ahmed S, Shackelford KA (2018). Factors influencing patients' satisfaction at different levels of health facilities in Bangladesh: Results from patient exit interviews. PLoS ONE, 13(5): 1-13. https://doi.org/10.1371/journal.pone.0196643

Alghamdi FS (2014). The impact of service quality perception on patient satisfaction in government hospitals in southern Saudi Arabia. Saudi Medical Journal, 35(10): 1271-1273. https://www.ncbi.nlm.nih.gov/pmc/articles/PMC4362118/pdf/SaudiMedJ-351271.pdf

Aliman NK, Mohamad WN (2016). Linking service quality, patients' satisfaction and behavioral intentions: an investigation on private healthcare in Malaysia. Procedia - social and behavioral sciences, 224(2016): 141-148. https://doi.org/10.1016/j.sbspro.2016.05.4 19.

Azwar S (2010). Pengantar administrasi kesehatan. Edisi 4. Jakarta: Binarupa Aksara.

Brubakk K, Vist GE, Bukholm G, Barach P, Tjomsland $O$ (2015). A systematic review of hospital accreditation: the challenges of measuring complex intervention effects. BMC Health Services Research, 15(1): 280-290. https://doi.org/10.1186/s12913-0150933-x

Camillo NR, Oliveira JL, Bellucci Jr, Cervilheri AH, Haddad MCFL, Matsuda LM (2016). Accreditation in a public hospital: perception of a multidisciplinary team. Revisia Brasileira de Enfermagem, 69(3): 423-430. http://doi.org/10.1590/0034-7167.20166- 
Journal of Health Policy and Management (2019), 4(3): 139-149

https://doi.org/10.26911/thejhpm.2019.04.03.01

$9306 \mathrm{i}$

Devkaran S, O'Farrell PN (2015). The impact of hospital accreditation on quality measures: An interrupted time series analysis quality, performance, safety and outcomes. BMC Health Services Research, 15(1): 137-151. doi: 10.1186/s12913-015-0784-5

Fuad L, Tamtomo D, Sulaiman ES (2017). Multilevel analysis on the effect of marketing mix strategy toward patient satisfaction in Magelang, Central Java. Journal of health policy and management, 4(1): 39-46. https://doi.org/10.26911/thejhpm.2019.04.01.05

Government of Indonesia (2009). UndangUndang Republik Indonesia Nomor 44tentang rumah sakit. http://www.pdpersi.co.id/kanalpersi/data/regulas i/permenkes/pmk342017akreditasirs. pdf

Haj-Ali W, Bou L, Natafgi N, Kassak K (2014). Exploring the relationship between accreditation and patient satisfaction-the case of selected Lebanese hospitals. International Journal of Health Policy and Management, 3(6): 341-346. https://doi.org/10.15171/ijhpm.2014.116

Hidayati AN, Suryawati C, Sriatmi A (2014). Analisis hubungan karakteristik pasien dengan kepuasan pelayanan rawat jalan semarang eye center (SEC) rumah sakit islam sultan agung Semarang. Jurnal Kesehatan Masyarakat (e-Journal), 2(1). https://ejournal3.undip.ac.id/index.php/jkm/article/view/6367/6146.

Holtmann G, Sack C, Scherag A, Lutkes P, Gunther W, Jockel KH (2011). Is there an association between hospital accreditation and patient satisfaction with hospital care? A survey of 37 ooo patients treated by 73 hospitals. Inter- national journal for quality in Healthcare, 23(3): 278-283. https://10.1093/intqhe/mzro1.

KARS (2018). Standar Akreditasi Rumah Sakit. Edisi 1. Jakarta: Komite Akreditasi Rumah Sakit.

Kennedy GD, Tevis SE, Kent KC (2014). Is there a relationship between patient satisfaction and favorable outcomes?. NIH Public Access, 260(4): 5926oo.https://doi.org/10.1097/SLA.ooo0000000000932

Kim CE, Shin JS, Lee J, Lee YJ, Kim M, Choi A, Park KB, Lee HJ, Ha I (2017). Quality of medical service, patient satisfaction and loyalty with a focus on interpersonal-based medical service encounters and treatment effectiveness: A cross-sectional multicenter study of complementary and alternative medicine (CAM) hospitals. BMC Complementary and Alternative Medicine, 17(1): 174-182. https://doi.org/10.1186/s12906-017-1691-6

Kurniawan HD, Tamtomo D, Murti B (2019). Contextual effect of community health center on patient satisfaction of health care service in Ngawi, East Java. Journal of health policy and management, 4(1): 23-30. https://doi.org/10.26911/thejhpm.2019.04.01.03

Lupiyoadi R (2013). Manajemen Pemasaran Jasa. Jakarta: Salemba Empat.

Ministry Of Health Republic of Indonesia (2013). Peraturan Menteri Kesehatan nomor 71 Tahun 2013 tentang Pelayanan Kesehatan Pada Jaminan Kesehatan Nasional. http://www.depkes.go.id/resources/download/general/PMK \%20No.\%2071\%20Th\%202013\%20tt g\%20Pelayanan\%2oKesehatan\%20Pa da\%20JKN.pdf

Oliveira JLC, Gabriel CS, Fertonani HP, Matsuda LM (2017). Management 
changes resulting from hospital accreditation. Revista Latino-Americana de Enfermagem, 25(1): e2851. https://doi.org/10.1590/1518-8345.1394.2851

Oroh ME, Rompas S, Pondaag L (2014). Faktor-faktor yang berhubungan dengan tingkat kepuasan pasien rawat inap terhadap pelayanan keperawatan di ruang interna RSUD Noongan. Jurnal keperawatan, Ejournal Universitas Sam Ratulangi Manado, 2(2). https://ejournal.unsrat.ac.id/index.$\mathrm{php} / \mathrm{jkp} /$ article/view/5220/4734

Péfoyo AJK, Wodchis WP (2013). Organizational performance impacting patient satisfaction in Ontario hospitals: a multilevel analysis. BioMed central research notes, 2013(6): 509. http://www.biomedcentral.com/1756-0500/6/509.

Sack C, Lutkes P, Gunther W, Erbel R, Jockel KH, Holtman GJ (2010). Challenging the holy grail of hospital accreditation: A cross sectional study of inpatient satisfaction in the field of cardiology. BioMed central health services Research, 23(3): 278-283. https://doi.org/10.1093/intqhc/mzro11

Sari PA (2015). Perbedaan Tingkat Kepuasan Pasien BPJS dengan Pasien Umum di RSUD Dr. Soedira Mangun Sumar- so Wonogiri. Medicine, 151(1): 10-17. https://doi.org/10.1145/3132-847.3132886

Sumarwan U (2011). Perilaku Konsumen: Teori dan Penerapannya dalam Pemasaran. Jakarta: Rineka Cipta.

Tjiptono F (2014). Pemasaran Jasa. Yogyakarta: Penerbit Andi.

Widayati MY, Tamtomo D, Adriani RB (2018). Factors affecting quality of health service and patient satisfaction in community health centers in North Lampung, Sumatera. Journal of Health Policy and Management, 02 (02): 165-175. https://doi.org/10.26911/thejhpm.2017.02.02.08.

Yogyakarta Health Office Province (2017). Profil Kesehatan Propinsi Yogyakarta tahun 2017. ttp://www.depkes.go.id/resources/download/profil/PROFIL _KES_PROVINSI_2017/14_DIY_201 7.pdf

Zarei E, Daneshkohan A, Pouragha B, Marzhan S, Arab M (2014). An empirical study of the impact of service quality on patient satisfaction in private hospitals, Iran. Global Journal of Health Science, 7(1). http://dx.doi.org/10.5539/gjhs.v7n1p1. 